\title{
REPRODUKSI GENDER MELALUI TRANSMISI TEKS AGAMA
}

Misbah Zulfa Elizabeth

\author{
IAIN Walisongo Semarang \\ misbah.zulfa.elizabeth@gmail.com
}

\begin{abstract}
The sustainability and cultural change, including gender, was associated with the delivery of value between generations. The existence of well-established interpretation of the text, which does not allow a new interpretation of the text, which is delivered to religious community make gender values remained relatively unchanged, even continuously reproduced. In this case, the transmitter of religious value, the preachers, seen in the Muslim community as the respectable and credible persons. Therefore, the doctrine they convey tend to be trusted and obeyed, without any possibility of other interpretations. The delivery model of one-direction model of messages delivery with lack of dialogue and participation of the audiences, no chance to new interpretations are another causes that led the concept of gender relatively unchanged.
\end{abstract}

Key words: gender, value transmission, religious community, new interpretation, reproduction of value

\section{Pendahuluan}

Realitas manusia terdiri dua jenis kelamin, yaitu laki-laki dan perempuan. Perbedaan jenis kelamin (sex difference) antara laki-laki dengan perempuan telah menimbulkan konsekuensi pembedaan antara kedua jenis kelamin itu. Pembedaan itu berkait dengan fungsi dan peran yang yang diharapkan oleh komunitas dan masyarakat. Peran dan fungsi yang diharapkan oleh masyarakat terhadap lakilaki dan perempuan itu yang kemudian dikenal sebagai gender. Dengan demikian gender adalah istilah yang merujuk pada peran dan fungsi laki-laki dan perempuan yang dikonstruksi secara sosial budaya. ${ }^{\top}$ Realitas budaya, termasuk gender, bersifat relatif, dapat berubah bersama waktu dan menunjukkan keragaman antar tempat dan lingkungan. 
Sebagai sebuah realitas sosial budaya, gender berasal dari nilai yang dirujuk oleh suatu masyarakat. Nilai yang mendasari gender dapat berupa agama atau sumber nilai lainnya, misalnya mitos-mitos, legenda, atau pepatah-petitih yang diucapkan oleh orang-orang tua. ${ }^{2}$ Persoalannya menjadi menarik karena sebagai sebuah realitas budaya, gender sulit berubah. Sifat, peran dan fungsi dari suatu jenis kelamin tertanam kuat dalam image masyarakat.

Perubahan gender diharapkan karena problem banyaknya kasus ketidakadilan gender yang muncul dalam masyarakat. Mengingat sumber nilai gender antara lain adalah agama, maka dengan mengacu pada fenomena yang ada dalam masyarakat muslim, tulisan ini akan mengkaji apa saja teks agama yang bermuatan gender yang seringkali disampaikan dalam forum-forum agama dan bagaimana teks agama itu ditransmisikan. Dengan melihat hal-hal tersebut akan tampak kondisi yang menyebabkan gender menjadi relatif tidak berubah. Pemahaman akan kondisi tersebut akan memungkinkan disampaikannya pemahaman yang baru terhadap teks serta cara penyampaiannya sehingga efek yang dimunculkan dari proses transmisi itu adalah efek relasi gender yang semakin adil. Untuk membicarakan hal itu, tulisan ini akan diawali dengan pembahasan tentang gender dan keadilan gender, kemudian dilanjutkan dengan pembicaraan tentang gender dan ketidakadilan gender, teks atau ayat-ayat yang terkait dengan gender yang sering kali disampaikan, dan forum di mana teks disampaikan

\section{Diskursus tentang Gender dan Keadilan Gender}

Pembicaraan tentang gender selalu dikaitkan dengan istilah keadilan gender. Adanya asumsi bahwa hubungan antara laki-laki dan perempuan terjalin dengan relasi kekuasaan (relation of power) menjadikan adanya upaya untuk menghubungkan kedua istilah tersebut. Adanya asumsi relasi kekuasaan dalam hubungan antara laki-laki dan perempuan itu membuat pembicaraan ini semakin lama semakin mengundang perhatian karena dalam relasi kekuasaan posisi pihak yang berelasi adalah posisi superior dan subordinate.

Istilah keadilan gender (gender equality) ${ }^{3}$ sendiri merupakan istilah yang sangat kompleks dan kontroversial. Hingga saat ini belum ada konsensus mengenai apa yang disebut keadilan atau kesetaraan gender. ${ }^{4}$ Salah satu pandangan mengenai keadilan dan kesetaraan gender yang belakangan ini berkembang menyatakan bahwa keadilan dan kesetaraam gender merupakan dua istilah yang 
tidak sama, namun saling mengkait. Istilah keadilan gender dimaknai sebagai suatu proses yang seimbang antara laki-laki dan perempuan dalam memperoleh akses/kesempatan, partisipasi, kontrol dan manfaat pembangunan dan hak-hak dasar; sementara kesetaraan gender adalah suatu kondisi yang sama antara laki-laki dan perempuan dalam mencapai hak-hak dasar dan manfaat pembangunan dalam lingkup keluarga, masyarakat, negara dan dunia internasional. ${ }^{5}$ Namun demikian, dalam kajian gender biasanya istilah ini biasanya dipahami sebagai istilah yang berkait erat dengan istilah marginalisasi, subordinasi, penindasan, serta berbagai perlakuan tidak adil yang dialami oleh salah satu jenis kelamin, yang biasanya adalah perempuan. ${ }^{6}$

Dalam diskursus mengenai keadilan gender, telah dikemukakan antara lain oleh kaum egalitis bahwa keadilan gender ideal adalah kesetaraan 50/50. Keadilan gender di sini dipahami sebagai kesetaraan lot yang harus dialokasikan secara sama rata kepada setiap individu. Konsep kesetaraan ini ditetapkan dengan asumsi dasa bahwa setap manusia memiliki aspirasi, keinginan, dan kebutuhan yang sama. ${ }^{7}$ Adanya asumsi mengenai aspirasi, keinginan, dan kebutuhan yang dimiliki oleh setiap individu ini memiliki implikasi bahwa individu itu mempunyai hak untuk menyampaikan spirasi, keinginan, dan kebutuhan dirinya tersebut.

Konsep kaum egalitis di atas ditentang oleh Elizabeth Wolgast dalam bukunya Equality and the Right of Woman (1980). Menurut Wolgast, konsep 50/50 tidak dapat diterima karena menghilangkan keragaman biologis antara laki-laki dengan perempuan. Menurutnya, laki-laki dan perempuan merupakan mahluk yang berbeda, yang memiliki kekuatan, kelemahan, dan kecenderungan yang berbeda. Konsep kesetaraan yang mempertimbangkan jenis kelamin itu selanjutnya disebut "kesetaraan kontekstual".

Konsep kesetaraan yang lain dikemukakan oleh Douglas Rae dalam bukunya Equalities. Menurutnya kesetaraan adalah kesetaraan dalam kesempatan (equality of opportunity), yang secara implisit juga mencakup kesetaraan kontekstual. ${ }^{9}$ Menurut Rae, konsep kesetaraan ini tidak sama dengan kesetaraan lot (kesetaraan 50/50) . Jadi, kesempatan untuk memperoleh lot seperti kekuasaan, hak-hak, pendidikan dan kekayaan memang harus sama, namun lot itu sendiri tidak bisa setara. Sebagai contoh, semua lulusan SLTA memiliki kesempatan untuk memperoleh lot di PTN Unggulan, 
MISBAH ZULFA ELISABETH: Reproduksi Gender Melalui Transmisi...

namun lot itu sendiri tidak dapat setara karena hanya didapat oleh mereka yang memiliki kemampuan baik, mereka yang berada dalam kualifikasi "terpandai".

Gagasan Douglas Rae di atas didukung oleh John Rawls dalam bukunya $A$ Theory of Justice yang menurutnya bahwa kesetaraan berarti "those with similar abilities and skills should have the same life chances" (bagi mereka yang memiliki kemampuan dan keahlian yang sama harus memiliki kesempatan yang sama). ${ }^{10}$ Kesempatan ini terbuka tanpa melihat perbedaan ras, agama, atau gender. Jadi jika terjadi pelanggaran atas kesempatan itu maka berarti telah terjadi ketidakadilan.

Jika kita amati pembahasan mengenai keadilan gender di atas, dapat disimpulkan bahwa keadilan gender adalah kesetaraan dalam pemberian kesempatan untuk memperoleh lot tertentu. Dengan demikian, jika seorang laki-laki dan seorang perempuan memiliki kemampuan yang sama serta memenuhi kualifikasi tertentu yang ditetapkan untuk suatu posisi tertentu maka keduanya harus diberi hak untuk sama-sama dipilih, tanpa membedakan jenis kelamin masing-masing.

Para ahli menyatakan bahwa keadilan gender ini merupakan salah satu fondasi bagi tercapainya keadilan sosial, dan keadilan sosial merupakan ciri dari civil society (masyarakat madani), yaitu tatanan masyarakat demokratis. Salah satu ciri masyarakat demokratis adalah jika setiap unsur dari masyarakat itu dihargai kehadiran dan andilnya bagi berjalannya masyarakat itu. ${ }^{11}$

\section{Realitas Gender dan Ketidakadilan Gender}

Realitas gender mengacu pada proses produksi dan reproduksi persepsi publik mengenai bagaimana peran laki-laki dan perempuan ditetapkan dalam masyarakat. ${ }^{12}$ Gender tidak mengacu semata-mata pada salah satu jenis kelamin, namun berkait dengan bagaimana kedua jenis kelamin itu berintaeraksi. ${ }^{13}$

Dalam masyarakat Islam konsep gender ditetapkan dengan menggunakan politik perbedaan sebagai rejim untuk memproduksi serangkaian norma, nilai, penghargaan, larangan, disiplin, dan hukuman yang membentuk moralitas laki-laki dan perempuan. Retorika ini membentuk persepsi publik mengenai kebenaran. ${ }^{14}$ Dalam perjalananya, konsep masyarakat tentang laki-laki dan perempuan ini berdialog dengan nilai-nilai lain. Dalam kajian Kroeber, mengenai kebudayaan dunia, hampir semua suku bangsa 
memiliki nilai yang patrialchal, yaitu nilai yang mengagungkan kekuasaan (power) laki-laki. Kesadaran akan adanya Kajian tentang gender dalam Antropologi telah lama dimulai, yaitu Konstruksi sosial budaya itu ditetapkan secara kuat dalam bentuk ajaran-ajaran agama, adat, mitos, dongeng serta pepatah dan petitih. Ajaran-ajaran agama, adat, mitos dan lainnya itu direpresentasikan secara terus menerus sehingga menghegemoni masyarakat sebagai pendukung budaya yang bersangkutan.

Salah satu konstruksi budaya mengenai laki-laki dan perempuan adalah anggapan bahwa laki-laki kuat, mampu, bertanggungjawab dan rasional; sementara perempuan lemah, tidak mampu, tergantung dan emosional. Yang menarik, terdapat mitos yang memperkuat anggapan itu. Sebagai contoh adalah mitos peran perempuan di Jawa, yaitu "ma-telu" (tiga ma), yaitu masak (memasak), macak (berhias) dan manak (melahirkan); sementara mitos untuk peran laki-laki dengan "ma-lima" yaitu main, minum, madat, maling, dan madon (berjudi, minum, menghisap candu, mencuri, dan main perempuan). ${ }^{16}$ Dialektika antara pandangan yang berkembang secara social dengan mitos-mitos tersebut semakin menguatkan konsep pembedaan tentang laki-laki dan perempuan, yang pada akhirnya pembedaan peran diskriminatif antara perempuan dengan laki-laki tersebut merupakan fenomena yang secara mudah dapat kita lihat dalam masyarakat.

Jika kita mengamati muatan mitos peran laki-laki-perempuan Jawa tersebut di atas, kita melihat adanya pembedaan peran (difference role), di mana peran perempuan "dibelenggu" dalam peran kerumahtanggaan sementara laki-laki bebas melakukan aktifitas yang diinginkannya. Efek jauh dari mitos dan anggapan di atas adalah ketidakdilan gender (gender inequality), karena masingmasing jenis kelamin telah disekat kehendak dan keinginan serta cita-citanya menurut standar yang dimiliki oleh masyarakat. Perempuan dinyatakan lebih tepat untuk melakukan aktifitas dalam ranah "domestik" sementara laki-laki dalam ranah "publik". ${ }^{17}$ Realitas pensekatan inilah yang kemudian menimbulkan ketidakadilan gender.

Berbagai bentuk ketidakadilan gender misalnya, pertama, marginalisasi perempuan (pemiskinan ekonomi terhadap perempuan.). Dapat diambil contoh berkait dengan marginalisasi perempuan ini, misalnya tersingkirkannya perempuan di pedesaan akibat diberlakukannya program pertanian Revolusi Hijau yang 
hanya memfokuskan programnya untuk lak-laki. Bentuknya antara lain dengan hilangnya kesempatan perempuan desa untuk ikut memanen padi karena model padi yang diintrodusir tidak memungkinkan penggunaan ani-ani, namun sabit, sehingga laki-laki lebih dominan untuk melakukan pekerjaan itu. Penyuluhanpenyuluhan dan berbagai pelatihan pertanian juga hanya diperuntukkan bagi petani laki-laki. ${ }^{18}$ Dengan demikian perempuan terbatasi aksesnya dalam memperoleh pengetahuan mengenai peningkatan usaha pertanian. Di sektor lain selain pertanian, ada anggapan bahwa perempuan lebih cocok untuk menangani pekerjaan-pekerjaan tertentu seperti 'guru taman kanak-kanak' dan 'sekretaris'. Dalam bidang perburuhan, perempuan juga dipandang kurang mampu sehingga terjadi pembedaan upah antara perempuan dengan laki-laki.

Kedua, subordinasi perempuan. Dalam hal ini di berbagai lapisan masyarakat, dari level rumah tangga hingga level negara, banyak kebijakan yang tidak memperhatikan kepentingan perempuan. Sebagai contoh misalnya adalah bahwa karena anggapan bahwa pada akhirnya perempuan akan ke dapur, maka perempuan tidak perlu mengenyam pendidikan yang tinggi. Demikian juga dengan anggapan bahwa perempuan berpembawaan emosional, maka perempuan tidak layak menjadi pemimpin. ${ }^{19}$ Fenomena ini sangat jelas dalam masyarakat Indonesia di mana jika dalam suatu wilayah kerja terdapat kesempatan yang sama bagi lakilaki dan perempuan untuk menduduki jabatan kepemimpinan, maka laki-laki yang akan diberi kesempatan yang lebih besar. Ketiga, pelabelan negatif terhadap jenis kelamin tertentu. Sebagai contoh adalah anggapan bahwa laki-laki adalah pencari nafkah (bread winer) maka setiap pekerjaan yang dilakukan oleh perempuan, betapa pun nilai ekonomisnya dianggap sebagai 'tambahan' dan karenanya boleh dibayar lebih rendah. Sebagai contoh adalah pekerjaan sebagai sopir dan pekerjaan sebagai pembantu rumah tangga. Anggapan bahwa pekerjaan sopir adalah pekerjaan laki-laki sebagai pencari nafkah membuat perejaan itu dinilai lebih mahal dibanding pekerjaan sebagai pembantu rumah tangga. ${ }^{20}$ Yang menarik dari kenyataan di mana perempuan memiliki nilai keberhasilan ekonomis yang lebih tinggi dibanding suami mereka, mereka tetap mengatakan bahwa hasil yang mereka peroleh "lumayan kangge tambah-tambah". ${ }^{21}$ Ungapan para perempuan tersebut menunjukkan nilai yang mereka pegangi bahwa perempuan 
"hanya" berperan sebagai pembantu suami dalam mencari nafkah. Penanggungjawab utama dalam mencari nafkah adalah suami. Padahal sebagaimana diungkap dalam hasil penelitian mengenai penghasilan keluarga yang dilaksanakannya di Gentuk Klaten oleh Jutta Berninghausen dan Brigit Kerstan , perempuan memberikan kontribusi lebih kurang 48 persen dibanding laki-laki yaitu 52 persen untuk keseluruhan penghasilan keluarga. ${ }^{22}$ Kajian mengenai realitas perempuan pekerja di Indonesia ${ }^{23}$ menunjukkan bahwa sesungguhnya aktifitas publik perempuan yang bernilai ekonomis demikian tinggi dan tidak bisa diabaikan begitu saja. Ungkapan yang terkesan "inferior" dari perempuan dalam mendapatkan sumber ekonomi merupakan kenyataan bahwa terdapat beban budaya

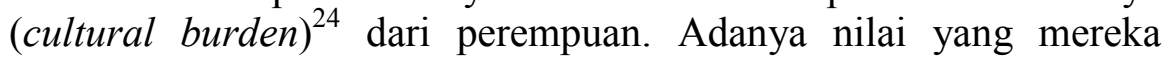
pegangi bahwa pencari nafkah adalah laki-laki membuat mereka tidak nyaman mengakui penghasilan yang lebih tingi dibandingkan yang didapatkan oleh laki-laki.

Keempat, kekerasan (violence) terhadap jenis kelamin tertentu, umumnya perempuan. Kekerasan ini ini dapat berbentuk pemerkosaan dan pemukulan, hingga kekerasan dalam bentuk yang lebih halus seperti pelecehan (sexual harassment) serta penciptaan ketergantungan. Kekerasan semacam ini muncul karena anggapan bahwa perempuan adalah mahluk lemah sehingga laki-laki boleh saja memukul dan memperkosa perempuan.

Kelima, karena peran gender perempuan adalah mengelola rumah tangga, maka banyak perempuan yang menanggung beban kerja domestik yang lebih berat dan lebih lama (overburden). Jadi, peran gender perempuan adalah mengelola, menjaga, dan memelihara kerapihan rumah tangga. Sosialisasi atas peran tersebut mengakibatkan munculnya rasa bersalah pada perempuan ketika perempuan itu tidak dapat melaksanakan tugas-tugas itu. ${ }^{25}$ Lima peran wanita yang ditetapkan menurut versi PKK, yaitu wanita sebagai istri pendamping suami, wanita sebagai penerus keturunan,pengelola rumah tangga,wanita sebagai anggota masyarakat, dan wanita sebagai pencari penghasilan tambahan, ${ }^{26}$ ikut mensosialisasikan beban berat yang ditimpakan atas perempuan.

\section{Teks Agama dalam Pembentukan Gender}

Sebagaimana dipahami, agama seseorang merupakan kombinasi yang bermakna bagi seorang individu. Kombinasi itu 
MISBAH ZULFA ELISABETH: Reproduksi Gender Melalui Transmisi...

meliputi unsur keyakinan, nilai, dan praktek yang biasanya terkait dengan pandangan dunia dari masyarakat yang mempengaruhi pandangan individu. Pandangan yang dimiliki masyarakat tersebut mempengaruhi individu sebagai anggota masyarakat karena disosialisasikan melalui orang tua, guru maupun tokoh masyarakat. ${ }^{27}$ Pandangan tersebut menjadi nilai yang dominan di dalam masyarakat. Nilai yang dominan itu kemudian diinternalisir oleh individu dalam masyarakat dan dipegangi dengan kuat sehingga menjadi milik individu-individu di dalam masyarakat. Kenyataan tersebut juga terkait dengan system makna tentang peran dan fungsi laki-laki dan perempuan, dan sumber pembentuk peran dan fungsi laki-laki dan perempuan dalam masyarakat yang sangat dominan adalah agama. $^{2}$

Terkait dengan pembentukan sistem makna atau konsep itu dalam masyarakat muslim, penting untuk mengungkap teks yang disampaikan oleh para mubaligh dalam forum-forum tabligh yang lazimnya dalam masyarakat muslim berbentuk pengajian. Teks yang seringkali disampaikan oleh para tokoh agama ketika menyampaikan nilai-nilai yang terkait dengan gender adalah teks yang memuat mitos kejadian manusia (the myth of the origin) dan fungsi diri lakilaki dan perempuan. Dalam al-Qur' an ada beberapa konsepsi tentang kejadian manusia, yaitu asal-usul manusia sebagai makhluk biologis, asal usul spesies manusia pertama, dan proses reproduksi manusia.

Dalam membicarakan tentang asal-usul manusia sebagai makhluk biologis, al-Qur'an menyatakan bahwa manusia, sebagaimana juga makhluk hidup yang lain, berasal dari air. Hal ini dinyatakan dalam beberapa ayat al-Qur'an, misalnya, pada Q.S AlAnbiyaa (21:3) ${ }^{*}$; Q.S. Al-An'am (6:99) dan Q.S. An-Nur (24:45) Dalam ayat-ayat di atas ditegaskan bahwa manusia diciptakan dar air. Perdebatan di kalangan ilmuwan menegaskan hal ini. ${ }^{29}$

Terkait dengan asal usul spesies manusia pertama al-Qur'an menyatakan bahwa manusia berasal dari tanah. Beberapa ayat yang menjelaskan hal itu misalnya Q.S. Nuh (71:17-18); Q.S. Thaha (20:55); dan Q.S. Hud (11:61). Menurut ayat-ayat di atas, manusia, sebagaimana halnya mahluk biologis lainnya, berasal dari jenis tanah tertentu, dan bukan dari air. Namun demikian tidak berarti 
bahwa manusia tidak termasuk mahluk biologis yang menjadikan air sebagai sumber kehidupan vital. Tanah yang merupakan asal-usul kejadian manusia, bertempat di salah satu planet yang mengandung air. Dengan menyebut unsur tanah, maka dengan sendirinya mencakup unsur air di dalamnya. Air sebagai sumber vital dalam kehidupan manusia dijelaskan secara sangat jelas dalam proses reproduksi manusia. ${ }^{30}$

Sampai di sini sebenarnya tidak tampak adanya pembedaan antara laki-laki dengan perempuan. Teks-teks di atas membicarakan tentang substansi penciptaan dari manusia, baik laki-laki maupun perempuan. Ditegaskan dalam ayat-ayat di atas bahwa baik laki-laki maupun perempuan, keduanya diciptakan dari unsur yang sama, dan dalam mekanisme, substansi, serta struktur yang sama. Oleh karena itu, secara alamiah sebenarnya dalam teks al-Qur'an laki-laki dan perempuan tidak ada perbedaan .

Perdebatan dalam diskursus yang terkait dengan dua tema di atas, yaitu tentang asal-usul manusia sebagai makhluk biologis dan asal usul spesies manusia pertama, terkait dengan permasalahan apakah manusia tercipta dari air, atau dari tanah, atau dari keduanya. ${ }^{31}$ Salah satu pandangan menyatakan bahwa manusia, sebagaimana makhluk hidup lainnya berasal dari jenis tanah tertentu, dan bukan berasal dari air.

Namun demikian, dalam membicarakan tentang asal-usul reproduksi manusia, beberapa ayat dalam al-Qur' an, misalnya surat Al-Qiyamah (75:37), Al-Insan (76:2), dan Al-Sajdah (32:8) menyebutkan bahwa manusia terbentuk dari air. Nazaruddin Umar menegaskan bahwa ayat-ayat di atas menegaskan bahwa unsur air dominan dalam proses penciptaan manusia. Ini berbeda dengan dua proses sebelumnya yang ada dua pandangan, yaitu yang menyatakan bahwa manusia berasal dari jenis tanah tertentu, dan yang lain menyatakan bahwa kejadian manusia berasal dari air. ${ }^{32}$

Dari tiga proses kejadian manusia di atas, yang paling banyak disampaikan kepada jamaah oleh para mubaligh adalah proses penciptaan manusia pertama. Umumnya tiga teks yang lain, yaitu Surah An-Nisa ayat 1 (QS. 4:1), Al-A'raf ayat 11 (QS. 7:11), dan Al-Hijr ayat 28-29 (QS. 15:28-29) digunakan sebagai dasar pembahasan masalah tersebut.

Interpretasi terhadap ketiga ayat di atas telah memunculkan pandangan heirarchis mengenai teori penciptaan. Pandangan heirarchis tersebut telah memunculkan premis bahwa manusia 
berasal dari ayah yang satu, yaitu Adam. Berdasar pada kisah Adam dan Hawwa, baik para ilmuwan Islam serta muslim pada umumnya mempercayai bahwa Adam diciptakan secara lebih mulia dibandingkan dengan Hawwa. Interpretasi ini telah menjadi persepsi umum tentang kebenaran tersebut, yang pada akhirnya mengarahkan pandangan tentang status laki-laki dan perempuan. ${ }^{33}$

Mitos "tulang rusuk Adam" yang diinterpretasikan sedemikian rupa untuk mendukung ketidakadilan di antara laki-laki dan perempuan, sebenarnya merupakan nilai yang membicarakan tentang asal-usul kejadian manusia yang bukan Qur'an semata yang membicarakannya, namun juga kitab suci yang lain seperti Injil. Kedua kitab suci agama itu membicarakan tentang mitos kejadian manusia dalam beber apa penciptaan. Interpretasi al-Qur'an sendiri muncul dari ayat dalam Surah an-Nisa (QS 4:1) di atas, yang menyatakan penciptaan Adam dari "diri yang satu" (entity: min nafsin waahidah). ${ }^{34}$ Interpretasi tersebut kemudian diperkuat oleh hadits-hadits yang secara eksplisit menyebutkan kata "tulang rusuk" tersebut. Sebagai contoh adalah hadits yang diriwayatkan oleh Abu Hurairoh yang menyatakan bahwa "Rosulullah bersabda, 'Sesungguhnya perempuan seperti tulang rusuk, jika kalian mencoba meluruskannya ia akan patah. Tapi jika kalian membiarkannya maka kalian akan menikmatinya tetap dalam keadaan bengkok".

Perdebatan mengenai interpretasi tentang penciptaan Hawwa dari tulang rusuk Adam sebenarnya cukup panas dalam diskursus keilmuan Islam. Jane I. Smith ${ }^{35}$ dan Nazaruddin Umar menegaskan bahwa "mitos tulang rusuk" dalam penciptaan perempuan sangat "israiliyat", yaitu dipengaruh oleh kisah-kisah yang secara tradisi beredar di kalangan masyarakat Arab. Quraisy Shihab juga menyatakan bahwa kata bengkok dalam hadits di atas adalah sebuah perumpamaan, dan bukan substantif. ${ }^{36}$ Demikian pula mufassir seperti Ar-Razi bahwa secara bahasa penyebutan "dari diri yang satu" merupakan menyebutan atas proses genetis makhluk manusia, dan bukan realitas fisiknya. ${ }^{37}$ Leyla Ahmed $^{38}$ juga mempermasalahkan interpretasi interpretasi ayat yang memunculkan pemahaman adanya relasi superior-subordinated dalam hubungan antara Adam dan Hawwa.

Yang menarik bahwa perdebatan tersebut hampir tidak pernah sampai kepada jamaah. Para muballigh menyampaikan teks tersebut dengan cara seolah itulah satu-satunya teks yang harus diyakini kebenarannya. Oleh karena itu, yang disampaikan oleh para 
muballigh kepada jamaahnya adalah bahwa perempuan diciptakan dari tulang rusuk laki-laki.

Teks yang kedua yang seringkali disampaikan dalam forum tabligh di kalangan masyarakat muslim adalah mengenai fungsi pribadi laki-laki dan perempuan. Dalam membicarakan tentang fungsi pribadi seorang laki-laki dan perempuan, para muballigh seringkali menggunakan surat An-Nisa (4:34) sebagai dasar untuk perbedaan fungsi dan peran laki-laki dan perempuan. Pembicaraan tentang peran perempuan dalam konteks seperti ini juga telah mengundang perdebatan ilmiah di kalangan para ahli. Nazaruddin Umar membahas secara mendalam tema ini. ${ }^{39}$ Menurut Umar, permasalahan yang muncul dari ayat di atas, yang bermuara pada kesan diskriminatif laki-laki dengan perempuan diakibatkan oleh persoalan bahasa. Ada istilah tertentu (ar-rijal) yang diartikan dengan "laki-laki" dalam bahasa Indonesia, sebenarnya dapat bermakna tidak semata-mata laki-laki dalam makna fisik, namun bersifat kualitatif, terkait dengan kualitas individual, yang diperoleh melalui proses belajar individual dan sosial.

Kembali, dalam proses penyampaian tabligh oleh para mubaligh, apa yang tertuang di teks itulah yang disampaikan kepada jamaah. Jamaah tidak diberi kemungkinan untuk memperoleh informasi lain yang terkait dengan tema itu. Dalam menyampaikan materinya, sebagaimana tema tentang proses kejadian manusia, dalam tema fungsi pribadi laki-laki dan perempuan pun para mubaligh menambahkan beberapa hadits yang bersifat misoginis serta mitos-mitos dan nilai lokal untuk menguatkan isi dari materi yang disampaikannya terkait dengan dominansi laki-laki.

Budaya Arab pra-Islam yang sangat dekat hubungannya dengan budaya Islam seringkali disampaikan sebagai budaya yang sama dengan budaya Islam. Budaya Arab pra-Islam yang memandang bahwa laki-laki dan perempuan secara moral berbeda, yang memandang perempuan sebagai lawan dari laki-laki (yang dipandang sempurna), dengan konsekuensi adanya pandangan bahwa laki-laki memiliki kekuasaan atas perempuan, disampaikan dengan kesan seolah itu adalah budaya Islam. Proses penyampaian seperti ini juga dipandang telah mempengaruhi interpretasi Qur'an dan hadits Nabi pada level jamaah. ${ }^{40}$

Proses interpretasi Qur'an dan Hadits yang semcam inilah yang tersebar di kalangan masyarakat dan menjadi bahan bagi pengajian-pengajian di berbagai tempat yang disampaikan oleh 
MISBAH ZULFA ELISABETH: Reproduksi Gender Melalui Transmisi...

tokoh-tokoh agama setempat. Pembenaran atas pandangan gender ini telah memunculkan politik diskriminasi yang pada akhirnya memilah dunia laki-laki dan perempuan. ${ }^{41}$ Pemilahan antara laki-laki dengan perempuan akibat politik diskriminasi ini yang kemudian memunculkan ketidakadilan di berbagai bidang kehidupan.

Interpretasi lanjutpun terjadi. Konsep hubungan gender yang seringkali ditemukan dalam bentuk ketidakadilan dan pembedaan ini kemudian teraksentuasi dalam sistem patriarchal, yang kekuasaannya berlaku di berbagai sisi kehidupan sosial budaya, seperti bidang hukum, ekonomi, sosial, dan politik. ${ }^{42}$ Retorika seperti ini jika terus menerus dibiarkan maka akan semakin mengabadikan persepsi umum tentang kebenaran bahwa perbedaan alami antara laki-laki dan perempuan juga menyangkut perbedaan moral, sosial, budaya, dan tanggung jawab hukum, baik pada level pibadi maupun publik. Tentu saja perbedaan biologis memang demikian adanya, namun perbedaan ini tidak berimplikasi pada supremasi ekonomi atau politik dari satu jenis kelamin atas jenis kelamin yang lain. Proses panjang pembentukan budaya semacam itu telah memberikan akibat yang sangat luas. Dalam bidang politik, misalnya, ketika perempuan muslim akan tampil di lingkup publik, maka akan muncul kegamangan pribadi (Adelina,2004; Agustina. 2009) disamping secara umum masyarakat akan memberikan reaksi yang tidak positif karena dipandang tidak sesuai dengan nilai agama. $^{43}$ Kondisi semacam ini terjadi secara umum. ${ }^{44}$ Dalam konteks Indonesia kondisinya pun tidak berbeda, yaitu ketika undang-undang memandatkan quota perempuan yang dicalonkan sebagai anggota legislatif, tidak ada satu pun partai politik yang dapat mencapainya. ${ }^{45}$ Berbagai kajian menyatakan bahwa alasan yang menghambat keterlibatan perempuan dalam dunia politik adanya pandangan bahwa politik adalah dunia publik, yang merupakan dunia laki-laki. Pandangan yang sangat patriarchal seperti itu umumnya berasal dari interpretasi agama.

\section{Forum Tabligh sebagai Forum Reproduksi}

Sebagai sebuah media yang digunakan menyampaikan nilai agama, tabligh memiliki arti yang sangat penting untuk mentransmisikan nilai-nilai agama kepada jamaah. Realitas menunjukkan bahwa forum pengajian merupakan forum yang dapat ditemukan di mana-mana. Di semua lingkup kehidupan dapat ditemukan adanya forum tabligh atau kelompok pengajian. Satuan 
komunitas, seperti tempat tinggal, profesi, satuan kerja, bapakbapak, ibu-ibu, remaja, dan anak-anak semua memiliki forum pengajian. Untuk satuan tempat tinggal seperti RT, RW, kampung dan desa, serta masjid-masjid memiliki kelompok pengajian. Pada lingkup profesi dan satua kerja juga hampir selalu terdapat forum pengajian. Data dari Departemen Agama manunjukkan bahwa kelompok-kelompok pengajian yang tumbuh di kalangan masyarakat demikian berkembang dengan pesat bersama berjalannya waktu.

Hal ini sejalan dengan ciri Islam sebagai agama dakwah, yaitu agama yang memerintahkan penyebaran nilai-nilai Islam secara luas, kepada seluruh umat manusia. ${ }^{46} \mathrm{M}$. Arifin menegaskan bahwa dakwah Islam adalah suatu kegiatan mengajak, baik dalam bentuk lisan, tulisan, tingkah laku yang dilakukan secara sadar dan berencana dalam usaha mempengaruhi orang lain baik secara individual maupun secara kelompok agar timbul pengertian, kesadaran, sikap, penghayatan, serta pengamalan ajaran agama. ${ }^{47}$

Perintah dakwah dalam agama Islam ditegaskan dalam alQur'an surat An-Nahl ayat 125 ( Q.S. 16:125), "Serulah manusia kepada jalan Tuhanmu dengan cara yang baik dan pelajaran yang baik dan bantahlah mereka dengan cara yang baik. Sesungguhnya Tuhanmu lebih mengetahui tentang siapa yang tersesat dari jalanNya dan Dialah yang mengetahui orang-orang yang mendapat petunjuk". Perintah di atas berkait dengan orientasi seruan, yaitu ke jalan Allah serta cara dalam berdakwah, yaitu dengan cara yang baik. Orientasi kepada jalan Allah merupakan orientasi mutlak, yang merupakan satu-satunya orientasi, dan berkait dengan cara, berdasar surat di atas, harus dilakukan secara baik dan bijaksana, yang sesuai dengan obyek dakwah. Dengan cara yang baik tersebut tujuan dakwah akan berjalan dengan efektif.

Nilai-nilai yang disampaikan dalam dakwah Islam adalah amar makruf dan nahi munkar. Makna dari amar makruf dan nahi munkar adalah mengajak untuk berbuat baik dan menjauhi perbuatan buruk. Dengan nilai yang dibawakan dalam dakwah Islam ini dapat disimpulkan bahwa upaya dakwah Islam merupakan upaya yang sangat mulia. Orientasi ajakan ke arah kebaikan dan menghindarkan keburukan merupakan suatu upaya untuk mengkoridori manusia agar selalu berada pada "right track" (jalan yang benar). 
Berdasar kenyataan bahwa dakwah Islam adalah sebuah perintah agama, maka dapat dipahami apabila dakwah islam dilakukan secara massive. Banyak anggota komunitas Islam yang terlibat di dalamnya. Keterlibatan ini terkait dengan keterlibatan pengelolaan maupun pelaksanaan, dan partisipasi dalam forum pengajian tersebut. Keterlibatan tersebut didorong oleh semangat yang dilandaskan pada nilai-nilai agama sebagaimana disebutkan di atas. Semua anggota masyarakat muslim merasa berkewajiban untuk melaksanakannya. Ini sejalan dengan pernyataan Tremmel bahwa semangat keagamaan sifatnya sangat mendalam sehingga pengikutnya terdorong untuk melaksanakannya. Ada persoalan metapsikologi di dalamnya, yang tidak dapat dipahami begitu saja. $^{48}$

Yang menjadi persoalan terkait dengan pembicaraan tentang potensi forum pengajian sebagai media transmisi nilai adalah bahwa karena nilai yang dienkulturasikan (enculturated) adalah nilai patriarchal, maka nuansa yang terbangun juga patriarchal. Meskipun pengajian putri sebenarnya lebih "menjamur" namun pada level mubaligh, yang paling banyak terlibat adalah laki-laki. Perempuan dalam konteks ini umumnya adalah sebagai $m a d$ ' $u$, sebagai audience, atau participant.

Dalam konteks ini, para mubaligh, dengan sumber ilmu keislaman lama akan menyampaikan nilai-nilai lama yang telah mapan di dalam masyarakat. Nilai itulah yang terus menerus disampaikan. Nilai tersebut diterima dan dipercaya begitu saja karena umumnya dalam masyarakat muslim mubaligh adalah kyai. Kyai biasanya adalah tokoh masyarakat yang memiliki ilmu agama yang lebih dibandingkan masyarakat pada umumnya, serta menjadi rujukan bagi anggota komunitas. Dengan keahliannya dalam bidang ilmu agama itu biasanya kyai juga memiliki karisma tertentu, yang memperkuat posisi spiritualnya dalam masyarakat (Dhofier, 1994:55; Faqih, 2002:130). Pandangan yang tinggi terhadap agama membuat masyarakat bersikap demikian. ${ }^{49}$

Dalam pola hubungan yang heirarchis semacam itu mubaligh berposisi seperti patron dan klien. Hubungan patron-klien di sini dalam makna hubungan antar dua pihak yang sebagian besar melibatkan persahabatan instrumental, yaitu pihak yang lebih tinggi kedudukan sosial ekonominya (patron) menggunakan pengaruh dan sumber daya yang dimilikinya untuknmemberikan perlindungan atau keuntungan atau keduaduanya kepada pihak lain yang lebih rendah kedudukannya (klien), yang pada gilirannya klien itu membalas pemberian tersebut dengan memberikan dukungan dan bantuan kepada patron. ${ }^{50}$ Namun demikian 
dalam konteks hubungan patron-klien pada komunitas agama kelebihan patron utamanya adalah dalam bidang keilmuan agama. ${ }^{51}$

Dalam posisi semacam ini mubaligh sebagai patron seolah memiliki kekuatan autoritatif untuk menyampaikan nilai "kebenaran". Kondisi seperti ini selanjutnya kemudian memungkinkan berkembangnya politik interpretasi. Politik interpretsi dalam konteks ini maksudnya adalah upaya pelanggengan nilai dengan menggunakan kekuatan otoritatif yang ada. $^{52}$ Fenomena seperti ini sangat lazim ditemukan dalam masyarakat tradisional yang menempatkan tokoh masyarakat dalam posisi otoritatif.

Kondisi lain yang ditemukan dalam realitas dakwah Islam adalah model penyampaian dakwahnya yang menggunakan metode konvensional. Metode konvensional adalah metode ceramah secara monolog, ${ }^{53}$ meskipun sebenarnya terdapat pula model dakwah yang interaktif dan dialog. Model ceramah monolog ini cenderung seperti indoktrinasi sehingga kurang memunculkan ide-ide kreatif dari jamaah. Sebagaimana dinyatakan oleh Quraisy Shihab bahwa dakwah yang progresif adalah yang partisipatif. Hal ini karena dengan ada peran aktif jamaah dalam pembentukan kesepakatan konsep akan memungkinkan pelaksanaan nilai dengan kesadaran jamaah. ${ }^{54}$

Hal lain yang perlu dipertimbangkan dalam kaitan reproduksi nilai gender dalam forum tabligh ini adalah adanya kenyataan bahwa perempuan di dunia ketiga pada umumnya terabaikan minat dan kehendaknya sehingga mereka selalu menjadi obyek. Kenyataan seperti ini muncul karena, sebagaimana dinyatakan oleh Mohanty (dalam Martyn, 2005:20), perempuan di dunia ketiga hampir selalu tampil sebagai kelompok masyarakat miskin, berpendidikan rendah, terikat tradisi, terdomestikasikan, dan berorientasi pada keluarga.

Melihat kenyataan ini sebenarnya forum tabligh dalam masyarakat Islam merupakan media bagi perubahan budaya ke arah yang lebih adil, dan bukan dimanfaatkan untuk upaya establishment budaya yang telah mapan, yang nyata-nyata tidak adil. Apabila kenyataannya perempuan masih tersubordinasi sebagai anggota masyarakat, maka forum tabligh dapat menjadi sarana untuk menyampaikan nilai yang membebaskan perempuan dari hambatan psikologis, sosial, agama, dan politik yang menghambat kehidupan mereka. Ketika nilai tersebut diimplementasikan, maka akan memberdayakan kehidupan mereka melalui berbagai ketrampilan, pengetahuan, kekuasaan, dan otoritas yang diperlukan untuk pembuatan keputusan dan survival di dalam kehidupan mereka. 
MISBAH ZULFA ELISABETH: Reproduksi Gender Melalui Transmisi...

\section{Penutup}

Sebagai sebuah realitas budaya, gender akan berubah bersama waktu. Dengan melihat forum pengajian sebagai forum yang menjadi media bagi perubahan nilai budaya, maka dapat disimpulkan dalam kaitannya dengan reproduksi gender bahwa:

1. Keberlangsungan dan perubahan budaya, termasuk di dalamnya gender, terkait dengan penyampaian nilai itu antar generasi. Adanya tafsir teks yang established, yang tidak memungkinkan tafsir baru atas teks, yang disampaikan kepada jamaah menjadikan nilai gender relatif tidak berubah, bahkan terus menerus direproduksi atau diproduksi ulang.

2. Penyampai nilai, yaitu para mubaligh, dalam masyarakat muslim memiliki kedudukan yang dihormati dan dipercaya. Oleh karena itu ajaran yang disampaikannya cenderung dipercayai dan ditaati, tanpa memepertimbangkan kemungkinan adanya tafsir lain.

3. Adanya model penyampaian nilai yang pada umumnya dilakukan oleh orang-orang yang secara kuat memegang konsep yang telah mapan, cara penyampaian pesan secara yang satu arah, kurang bersifat dialog dan partisipatif, serta tidak membuka adanya tafsir bagi telah menyebabkan "established"nya nilai tersebut.

\section{CATATAN AKHIR}

${ }^{1}$ Mansour Fakih, Analisis Gender dan Transformasi Sosial (Yogyakarta: Pustaka pelajar, 1996), h. 10-11; Shelly Errington, "Recasting Sex, Gender, and Power: A Theoretical and Regional Overview" dalam Power and Difference: Gender in Island Southeast Asia (Stanford California: Stanford University Press, 1990), h. 25; Etin Anwar, Gender and Self in Islam (New York: Routledge, 2006), h. 32

2 Mansour Fakih, Analisis Gender; h. 10; dan Etin Anwar, Gender; h. 32

${ }^{3}$ Megawangi, Membiarkan Berbeda?: Sudut Pandang Baru dalam Relasi Gender (Bandung, Mizan, 1998), h. 21

${ }^{4}$ Elizabeth Martyn, The Women's Movement in Post-colonial Indonesia: Gender and Nation in a New Democracy, (New York: Routledge, 2005), h. 23

${ }_{6}^{5}$ Megawangi, Membiarkan Berbeda, h. 19

${ }^{6}$ Ibid., h. 47

${ }^{7}$ Ibid.

${ }^{8}$ Ibid., h. 48-49

9 John Rawls. A Theory of Justice, Cambridge, (Massachusetts, The Belknap Press of Harvard University Press, 1997), h. 65 
${ }^{10}$ Budhy Munawar Rachman "Refleksi Keadilan Sosial dalam Pemikiran Keagamaan" dalam Keadilan Sosial: Upaya Mencari Makna Kesejahteraan Bersama di Indonesia, (Jakarta: Penerbit Buku Kompas, 2004), h. 220

${ }^{11}$ Etin Anwar, Gender, 38

${ }^{12}$ Amin Abdullah, "Perspektif Gender dalam Studi Islam di IAIN, Pendekatan Kritis hermeneutis", Makalah disampaikan dalam Workshop Sensitifitas Gender bagi Ketua PA, Kepala KUA, BP4 dan Tokoh Islam se-propinsi Baten, 29 pebruari 2003, h. 23

${ }^{13}$ Etin Anwar, Gender, 38

${ }^{14}$ Arimbi et al., "Mitos Peran "Bukan Laki-laki" Masak, Macak, Manak: Dikaji Ulang..." dalam Perempuan dan Politik Tubuh Fantastis, (Yogyakarta, Kanisius, 1998), h. 8-9

${ }^{15}$ Ibid.

16 Irwan Abdullah, Irwan, "Dari Domestik ke Publik: Jalan Panjang Pencarian Identitas Perempuan" dalam Sangkan Paran Gender, Yogyakarta: Pustaka Pelajar, 1997), h. 63

${ }^{17}$ Mansour Fakih, Analisis Gender, h. 74

18 Mansour Fakih, Analisis Gender, h. 74-75; Barbara Rogers, The Domestication of Women: Discrimination in Developing Societies, (London dan New York: Tavistock Publication, 1980), h. 24

${ }^{19}$ Mansour Fakih, Analisis Gender, h. 74

20 Pratiwi, "Makanan (Tradisional) Modern dan Tubuh Industrif Perempuan" dalam Perempuan dan Politik Tubuh Fantastis, (Yogyakarta, Kanisius. (Elizabeh, 1998), h. 78-80: 3

21 TO Ihromi, "Paradigma Baru bagi Pengkajian Masalah Wanita dan Jender dalam Antropologi”" dalam Antropologi Indonesia, Th. XXIII, No. 60, 1999, h. 59

${ }^{22}$ Ford, Michele Ford dan Lyn Parker,ed., 2008. Women and Work in Indonesia, (New York: Routledge, 2008)

${ }^{23}$ Syafri Sairin, Mobilitas Sosial dan Beban Kultural: Tinjauan Antropologis Fenomena KKN Di Indonesia, Pidato Pengukuhan Jabatan Guru Besar pada Fakultas Sastra Universitas Gadjah Mada, 199

${ }^{24}$ Mansour Fakih, Analisis Gender, h. 75-76

${ }^{25}$ Rebeka Harsono, "Gerakan Perempuan: Antara Kepentingan Perempuan dan Politik Gender, dalam Irwan Abdullah (ed.). Sangkan Paran Gender, (Yogyakarta, Pustaka Pelajar, 1997), 275

26 Meredith McGuire, Religion: The Social Context, (Belmont California: Wadsworth Publishing Company, 1981), h. 89

${ }^{27}$ Ibid., h. 90

28 Nazaruddin Umar, Argumentasi Kesetaraan Gender Perspektif Al-Qur'an, (Jakarta: Paramadina, 1999), h. 216-217

${ }^{29}$ Ibid., h. 201-208

${ }^{30}$ Ibid., h. 217

${ }^{31}$ Ibid., h. 219-220

${ }^{32}$ Etin Anwar, Gender, h. 46 
33 Ibid., h. 46; Leila Ahmed Women and Gender in Islam,Historical Roots of a Modern Debate, (New Haven \& London: Yale University Press, 1992), h. 20

34 Jane I Smith,."Islam" dalam Perempuan dalam Agama-agama Dunia, (editor Arvind Sharma), Yogyakarta, Direktorat PTAI Departemen Agama bekerja sama dengan CIDA-McGill-Project, 2002), h. 282

35 M. Qurasy Shihab, Tafsir Maudhu'i atas Pelbagai Persoalan Umat, (Bandung: Mizan, 1996), h. 271

${ }^{36}$ Nazaruddin Umar, Argumentasi, h. 239

${ }^{37}$ Leila Ahmad, Women, h. 4-5

${ }^{38}$ Nazaruddin Umar, Argumentasi, h. 145-146

${ }^{39}$ Etin Anwar, Gender, h. 35

${ }^{40}$ Ibid., h. 56

${ }^{41}$ Shelly Errington, Recasting, h. 30; Etin Anwar, h. 48

${ }^{42}$ Etin Anwar, Gender, h. 49

${ }^{43}$ Josephine Caldwell Ryan, "Encountering the State: Cross-Cultural Perspectives on Women's Political Experience" dalam Gender in Cross-Cultural Perspective, editor Caroline B. Brettell dan Carolyn F. Sargent, (New Jersey: Prentice Hall, 2005), h. 322

${ }^{44}$ Misbah Zulfa Elizabeth, "Keterwakilan Perempuan di Lembaga Legislatif dan Gender" Disampaikan dalam Dialog Interaktif "Kuota 30\% Perempuan di legislatif: Idealis atau Politis" yang diadakan oleh LPM Missi FD IAIN Walisongo bekerja sama dengan Lembaga Studi dan Informasi Pembangunan, 8 September 2008 di Hotel Tugu Semarang, h. 3

45 M. Quraish Shihab, Tafsir, h. 378; Shaleh, Rosyad, Manajemen Dakwah Islam, Jakarta: Bulan Bintang, 1993), h. 1

${ }^{46}$ M Arifin, Psikologi Dakwah: Suatu Pengantar, (Jakarta: CV. Bumi Aksara, 200), h. 6

${ }^{47}$ William Calloley Tremmel, Religion: What is It? New York: Holt, Rinehart and Winston, 1976), h. 217

48 Zamakhsyari Dhofier, Tradisi Pesantren: Studi tentang Pandangan Hidup Kyai, Jakarta: LP3ES, 1994), h. 55

${ }^{49}$ James C Scott, Domination and Arts of Resistance, New Heaven: Yale University, 1990), h. 7

50 Anasom, "'Patronase' di Pondok Pesantren" dalam Merumuskan Kembali Interelasi Islam-Jawa, Yogyakarta: Gama Media-Pusat Pengkajian Islam dan Budaya Jawa, 2004), h. 150

${ }^{51}$ Mai Yamani, "Pengamatan terhadap Perempuan di Saudi Arabia” dalam Feminisme dan Islam: Perspektif Hukum dan Sastra, terj. Purwanto, (Bandung: Yayasa Nuansa Cendikia, 2000), h. 399-403

52 M. Quraish Shihab, Membumikan al-Qur'an, (Bandung: Mizan, 2004), h. 397

\footnotetext{
${ }^{53}$ Ibid.

${ }^{54}$ Sebagaimana dikutip Elizabeth Martyn, The Women's Movement,
} h. 20 


\section{DAFTAR PUSTAKA}

Abdullah, Amin, 2003, "Perspektif Gender dalam Studi Islam di IAIN, Pendekatan Kritis hermeneutis", Makalah disampaikan dalam Workshop Sensitifitas Gender bagi Ketua PA, Kepala KUA, BP4 dan Tokoh Islam se-propinsi Baten, 29 pebruari 2003.

Abdullah, Irwan, 1997.'Dari Domestik ke Publik: Jalan Panjang Pencarian Identitas Perempuan" dalam Sangkan Paran Gender, Yogyakarta: Pustaka Pelajar.

2001. Seks, Gender, \& Reproduksi Kekuasaan, Yogyakarta: Tarawang Press.

Afshar, Haleh, 2000. "Islamdan Feminisme: Suatu Analisis Strategi Politik" dalam Feminisme dan Islam: Perspektif Hukum dan Sastra, terj. Purwanto, Bandung: Yayasa Nuansa Cendikia.

Ahmed, Leila, 1992. Women and Gender in Islam,Historical Roots of a Modern Debate, New Haven \& London: Yale University Press.

Anasom, 2004. "'Patronase' di Pondok Pesantren" dalam Merumuskan Kembali Interelasi Islam-Jawa, Yogyakarta: Gama Media-Pusat Pengkajian Islam dan Budaya Jawa

Anwar, Etin, 2006.Gender and Self in Islam, New York: Routledge.

Arifin, M, 2000. Psikologi Dakwah: Suatu Pengantar, Jakarta: CV. Bumi Aksara.

Arimbi et al., 1998. "Mitos Peran "Bukan Laki-laki" Masak, Macak, Manak: Dikaji Ulang..." dalam Perempuan dan Politik Tubuh Fantastis, Yogyakarta, Kanisius.

Budiman, Kris, 1992, "Subordinasi Perempuan dalam Bahasa Indonesia" dalam Budi Susanto et al. (ed.). Citra wanita dan Kekuasaan (Jawa), Yogyakarta, Kanisius.

Departemen Agama Republik Indonesia, 1989. Al-Qur'an dan Terjemahannya, Semarang: Penerbit Toha Putra

Dhofier, Zamakhsyari, 1994. Tradisi Pesantren: Studi tentang Pandangan Hidup Kyai, Jakarta: LP3ES 
Elizabeth, Misbah Zulfa, 2008. "Keterwakilan Perempuan di Lembaga Legislatif dan Gender" Disampaikan dalam Dialog Interaktif "Kuota 30\% Perempuan di legislatif: Idealis atau Politis" yang diadakan oleh LPM Missi FD IAIN Walisongo bekerja sama dengan Lembaga Studi dan Informasi Pembangunan, 8 September 2008 di Hotel Tugu Semarang

Enginer, Asghar Ali. 2000. Hak-hak Perempuan dalam Islam, (terj. Farid Wajdi dan Cici Farkha Assegaf), Yogyakarta: Pustaka Pelajar

Errington, Shelly, 1990. "Recasting Sex, Gender, and Power: A Theoretical and Regional Overview" dalam Power and Difference: Gender in Island Southeast Asia, Stanford, California, Stanford University Press.

Fakih, Mansour, 1996, Analisis Gender dan Transformasi Sosial (Yogyakarta: Pustaka pelajar).

Faqih, Akhmad, 2004. "Perubahan Wewenang Karismatik Kyai" dalam Merumuskan Kembali Interelasi Islam-Jawa, Yogyakarta: Gama Media-Pusat Pengkajian Islam dan Budaya Jawa

Ford, Michele dan Lyn Parker,ed., 2008. Women and Work in Indonesia, New York: Routledge.

Harsono, Rebeka, 1997. "Gerakan Perempuan: Antara Kepentingan Perempuan dan Politik Gender, dalam Irwan Abdullah (ed.). Sangkan Paran Gender, Yogyakarta, Pustaka Pelajar.

Ihromi, TO, 1999. "Paradigma Baru bagi Pengkajian Masalah Wanita dan Jender dalam Antropologi" dalam Antropologi Indonesia, Th. XXIII, No. 60.

Irianto, Sulistyowati, 2004. "Keadilan Sosial, Apakah Juga Ditujukan bagi Perempuan?" dalam Keadilan Sosial: Upaya Mencari Makna Kesejahteraan Bersama di Indonesia, Jakarta: Penerbit Buku Kompas

Martyn, Elizabeth, 2005. The Women's Movement in Postcolonial Indonesia: Gender and Nation in a New Democracy, New York: Routledge

McGuire, Meredith, 1981. Religion: The Social Context, Belmont California: Wadsworth Publishing Company

TEOLOGIA, VOLUME 23, NOMOR 1, JANUARI 2012 
Megawangi, 1998. Membiarkan Berbeda?: Sudut Pandang Baru dalam Relasi Gender, Bandung, Mizan.

Morris, Brian, 2006. Religion and Anthropology: A Critical Introduction, New York: Cambridge University Press.

Mosse, Julia Cleves, 1993. Gender dan Pembangunan, Yogyakarta, Pustaka Pelajar.

Pratiwi, 1998. "Makanan (Tradisional) Modern dan Tubuh Industrif Perempuan" dalam Perempuan dan Politik Tubuh Fantastis, Yogyakarta, Kanisius. (Elizabeh, 2008: 3)

Rachman, Budhy Munawar, 2004. "Refleksi Keadilan Sosial dalam Pemikiran Keagamaan" dalam Keadilan Sosial: Upaya Mencari Makna Kesejahteraan Bersama di Indonesia, Jakarta: Penerbit Buku Kompas

Rahardjo, Dawam, 2000. "Masyarakat Madani" dalam Bahan Bacaan Loka Karya Islam dan Pemberdayaan Civil Society di Indonesia yang dilaksanakan oleh Walisongo Research Institute (WRI) IAIN Walisongo bekerjasama dengan Pusat Pengkajian Islam dan Masyarakat (PPIM) IAIN Jakarta dan Ford Foundation,13-14 Juni 2000 di Semarang.

Rawls, John, 1997. A Theory of Justice, Cambridge, Massachusetts, The Belknap Press of Harvard University Press.

Ryan, Josephine Caldwell, 2005. "Encountering the State: CrossCultural Perspectives on Women's Political Experience" dalam Gender in Cross-Cultural Perspective, editor Caroline B. Brettell dan Carolyn F. Sargent, New Jersey: Prentice Hall

Rogers, Barbara, 1980. The Domestication of Women: Discrimination in Developing Societies, London dan New York: Tavistock Publication

Sairin, Syafri, 1999. Mobilitas Sosial dan Beban Kultural: Tinjauan Antropologis Fenomena KKN Di Indonesia, Pidato Pengukuhan Jabatan Guru Besar pada Fakultas Sastra Universitas Gadjah Mada

Scott, James C, 1990. Domination and Arts of Resistance, New Heaven: Yale University 
MISBAHZULFA ELISABETH: Reproduksi Gender Melalui Transmisi...

1993. Perlawanan Kaum Tani, terj. Budi Kusworo dkk., Jakarta: Yayasan Obor Indonesia

Shaleh, Rosyad, 1993. Manajemen Dakwah Islam, Jakarta: Bulan Bintang .

Shihab, M. Qurasy, 1996. Tafsir Maudhu'i atas Pelbagai Persoalan Umat, Bandung: Mizan

-------------------, 2004. Membumikan al-Qur'an, Bandung: Mizan

Smith, Jane I., 2002. "Islam" dalam Perempuan dalam Agama-agama Dunia, (editor Arvind Sharma), Yogyakarta, Direktorat PTAI Departemen Agama bekerja sama dengan CIDA-McGill-Project

Sutarti, Nurul, dkk, 2008. Menyibak Tabir Perempuan Berpolitik, Surakarta: Yayasan Krida Paramita Surakarta.

Tremmel, William Calloley, 1976. Religion: What is It? New York: Holt, Rinehart and Winston.

Umar, Nazaruddin, Umar, 1999. Argumentasi Kesetaraan Gender Perspektif Al-Qur'an, Jakarta: Paramadina.

------------------------, 2004, "Isu-isu ketidakadilan Gender dalam Islam”, Makalah disampaikan dalam Workshop Sensitivitas Gender bagi Guru Madrasah Aliyah se DI Yogyakarta, Pusat Studi Wanita, UIN Yogyakarta, 27 Agustus 2004. in Islam.

Wadud, Amina, 1997. Women in the Qur'an,Malaysia: Sister

Yamani, Mai, 2000. "Pengamatan terhadap Perempuan di Saudi Arabia" dalam Feminisme dan Islam: Perspektif Hukum dan Sastra, terj. Purwanto, Bandung: Yayasa Nuansa Cendikia. 